\title{
Clinic and demographic characteristics of pediatric patients with Lichen sclerosus
}

\author{
Ayşe Akbaş ${ }^{\circ}$, Fadime Kılınç \\ Department of Dermatology, Ministry of Health Ankara City Hospital, Ankara, Turkey.
}

\begin{abstract}
Background. Lichen sclerosus (LS) is a chronic disease of the skin, for which the pathogenesis is not known. It can lead to various changes of the skin and the genital area, potentially leading to both functional as well as cosmetic problems for the patient, thus disrupting the quality of life. In this study; the purpose was to review the clinical characteristics and the treatments of the 15 pediatric patients under the age of 18 followed up in our out-patient clinic with a diagnosis of LS and to compare the findings with literature data.
\end{abstract}

Methods. Between 2011 and 2017, the files of 15 patients diagnosed clinically and/or histologically with LS in our clinic were retrospectively examined. The demographic characteristics, clinic and laboratory findings, treatment options of the patients are reported.

Results. Of the patients included in the study 14 were girls and one was a boy. The average age was 11.6 years (5-17 years), the average age for the initial disease was 7.8 years (2-13 years). The average duration of the disease at the diagnosis was 3.9 years. The most common form was genital vulvar type (8/14 girls) without anal and cutaneous involvement, and each of them suffered from itching. One of the cases had genital LS as well as extragenital morphea lesions. Two of the 15 patients were ANA positive. The other antibodies were negative. In two cases with extragenital involvement, lesions were widespread and they were in blachkoid form.

Conclusion. LS is a chronic disease that progresses with recurrences and regressions. In our study, the most common LS type was genital type (60\%). There was extragenital involvement in 6 patients (40\%). Extragenital involvement was the most common on the trunk. Diagnosis, treatment and follow-up during childhood is highly important to prevent any possible future anatomical or psychological damage and genital malignancies.

Key words: child, epidemiology, extragenital, genital, lichen sclerosus.

Lichen sclerosus (LS) is a chronic inflammatory skin disease with genital and extragenital involvement and its cause is unknown. ${ }^{1}$ It was defined for the first time by Halopeau ${ }^{2}$ in 1887. The International Vulvovaginal Diseases Study Group named the disease "Lichen sclerosus" in $1976 .{ }^{1,3}$ As patients are followed by many specialties such as dermatology, gynecology, urology and pediatrics, the incidence of LS is not known precisely. ${ }^{4}$ It is mostly seen in

Ayşe Akbaş

ayseakbas62@gmail.com

Received 19th December 2018, revised 21st February 2020, 22nd March 2020, accepted 30th May 2020.

This manuscript was presented at the congress of Pediatric Dermatology on 27-29 April 2018 in Kayseri. caucasians and the rate in women is 6-10 times higher. ${ }^{5}$ It has a bimodal starting age as in prepubertal and postmenopausal. ${ }^{5}$ The prevalence in dermatology clinics is estimated to be $1 / 300-1 / 1000.5,7,8$ Of the patients diagnosed with LS $10-20 \%$ are children ${ }^{7,9}$ and of these children $7-15 \%$ are prepubertal and $90 \%$ of these are between 3-13 years old.,10 In the prepubertal phase, lesions appear at around 5 years of age (average 5.4 years), but usually a diagnosis is only made at around the age of 6 to 7 years. ${ }^{8,11}$ The disease usually takes a chronic course with phases of exacerbations and remissions. The cause of LS is unknown, however, studies are focusing on autoimmunity, genetics, hormonal factors, various infections, local irritations and trauma. ${ }^{12-15}$ The most frequent site involved is on the genital area. 
Anogenital area involvement ranges between $85-98 \% .{ }^{1,9,14,16,17}$ Clinically, it starts in the genital area as an erythematous macule and papular lesion. White, atrophic, bright plaques develop overtime. Lesions resemble the shape of the number 8 around the vulva and anus. Due to the itching of the lesions, ecchymosis and petechial bleeding may occur on the genital area. Sclerosis, hyperkeratosis, erosion, fissure, ulceration and bulla may be observed. During the healing process, these lesions may cause postinflammatory hyperpigmentation.,13,15 Girls suffer anogenital itching, dysuria and painful defecation, while boys suffer from phimosis. Extragenital lesions occur in around $6-20 \%$ and clinically, they display similar characteristics to genital lesions. ${ }^{6,718}$ It is mostly seen in the neck, shoulders, upper body, wrist flexor surfaces. It is rarely seen on the palms, soles, hairy skin and face. ${ }^{19-21}$ Annular, blaschkoid, keratotic and bullous forms of this type have been reported. ${ }^{19-21}$ Koebnerization is frequent and LS with koebnerization may be accompanied by plaque type morphea. ${ }^{22,23}$ Some authors claim that LS and morphea have a common pathogenesis. ${ }^{11,22,24}$ Involvement of the genital area might lead to functional problems and skin involvement may cause cosmetic problems. ${ }^{4,6}$ Also, rarely, oral involvement has been reported..$^{25}$

Even though there are retrospective studies, examining various LS parameters in the literature. The studies from Turkey on this topic are mostly in the form of case reports. ${ }^{26-28}$

The purpose of this study was to examine the clinic and demographic characteristics of 15 pediatric patients diagnosed with LS whom we have monitored in our outpatient clinic, to assess laboratory findings, to examine the treatment options provided and compare them with literature data.

\section{Material and Methods}

The study was approved by Yildırım Beyazit University, Yenimahalle Training and Research
Hospital Ethics Committee (Number 2017/09/03; Date: 24/10/2017). The medical charts of patients diagnosed clinically and/or histopathologically for LS during 2011-2017 were retrospectively examined. The criteria to be involved in the study was set as being under 18 years of age at the time of diagnosis. The demographic characteristics of the patients, the starting age of the disease, its duration, clinic type, anatomic area, accompanying symptoms, triggering factors, laboratory findings, and applied treatment options were recorded. The existence of additional diseases that could accompany LS was also investigated. The data is presented in average and ranges, categorical data has been provided in percentage, in figures.

\section{Results}

There were 15 pediatric LS patients diagnosed and followed at our outpatient clinic during the 2011- 2017 period. A biopsy had been taken from all cases with extragenital lesions and histopathologic assessments were made (Figs 1-3). A biopsy had been taken from a case with genital involvement who relapsed. The total number of patients to receive a biopsy was 8 . Diagnosis of others were made by history and clinical examination.

The demographic and clinic data, laboratory findings and treatments the subjects received are given in Table I. The age range was between 5 and 17 years (11.6 years on average). The duration of the disease was 3 months to 13 years (3.9 years on average). The starting age of the disease was 7.8 years. Of the patients $93.3 \%$ were girls $(n=14)$ and there was one boy $(n=1,6.7 \%)$. Girl to boy ratio was $14 / 1$. The most common LS type was genital type by $60 \%(n=9)$. This was followed by extragenital involvement in 6 patients (40\%). These patients had only extragenital involvement. Genital and extragenital involvement were not seen together. Skin lesions were mostly located on the trunk and lower extremity. In one girl, segmental lesions were observed on the lower extremity, while in another segmental lesions 
Table I. The characteristic features of the patients.

\begin{tabular}{|c|c|c|c|c|c|c|c|c|c|c|}
\hline No & Age & Gender & $\begin{array}{c}\text { Age } \\
\text { disease } \\
\text { started }\end{array}$ & $\begin{array}{l}\text { Disease } \\
\text { duration }\end{array}$ & Itching & $\begin{array}{c}\text { Area } \\
\text { involved }\end{array}$ & $\begin{array}{c}\text { Accompanying } \\
\text { disease }\end{array}$ & $\begin{array}{l}\text { ANA } \\
(+)\end{array}$ & Biopsy & Therapy \\
\hline 1 & 11 & $\mathrm{~F}$ & - & 1 Year & Yes & Genital & $\begin{array}{c}\text { Neuro } \\
\text { fibromatosis }\end{array}$ & - & - & $\mathrm{TS}, \mathrm{T}$ \\
\hline 2 & 17 & $\mathrm{~F}$ & 7 & 11 Years & - & Left Leg & & - & + & $\mathrm{K}+\mathrm{T}+\mathrm{C}+\mathrm{P}$ \\
\hline 3 & 12 & $\mathrm{~F}$ & 2 & 10 Years & Yes & Genital & $\begin{array}{l}\text { Vit D and Vit } \\
\text { B12 deficiency } \\
\text { Thyroid diseases }\end{array}$ & - & + & $\mathrm{TS}+\mathrm{T}$ relapse \\
\hline 4 & 11 & $\mathrm{~F}$ & 9 & 2 Years & - & $\begin{array}{l}\text { Bilateral leg } \\
\text { front sides }\end{array}$ & -- & + & + & TS \\
\hline 5 & 12 & $\mathrm{~F}$ & 10 & 2 Years & Yes & Back, trunk & - & - & + & $\mathrm{TS}+\mathrm{T}$ \\
\hline 6 & 7 & $\mathrm{~F}$ & 6 & 1 Year & Yes & Genital & Morphea & & + & $\mathrm{TS}+\mathrm{T}$ \\
\hline 7 & 14 & F & 10 & 4 Years & - & Genital & & & & TS \\
\hline 8 & 13 & $\mathrm{~F}$ & 7 & 6 Years & Yes & Genital & & & - & $\mathrm{TS}+\mathrm{K}$ \\
\hline 9 & 16 & F & 13 & 3 Years & Yes & Genital & - & & - & TS \\
\hline 10 & 14 & F & 11 & 3 Years & - & Trunk & - & - & + & $\mathrm{TS}$ \\
\hline 11 & 6 & $\mathrm{~F}$ & 4 & 2 Years & Yes & Genital & - & & & TS \\
\hline 12 & 10 & M & 7 & 3 Years & Yes & Genital -penis & - & - & - & $\begin{array}{c}\text { Circumcision } \\
\text { TS }\end{array}$ \\
\hline 13 & 17 & $\mathrm{~F}$ & 7 & 10 Years & - & $\begin{array}{c}\text { Blasckoid } \\
\text { and plaque in } \\
\text { trunk arm }\end{array}$ & $\begin{array}{c}\text { Iron, VitB12, } \\
\text { Vit D deficiency }\end{array}$ & + & + & $\mathrm{MTX}+\mathrm{T}$ \\
\hline 14 & 5 & F & 5 & 3 Months & Yes & Trunk, legs & - & - & + & TS \\
\hline 15 & 10 & $\mathrm{~F}$ & 9 & 9 Months & Yes & Genital & - & - & - & TS \\
\hline
\end{tabular}

$\mathrm{K}=$ Calcipotriol, $\mathrm{TS}=$ Topical Steroid, $\mathrm{T}=$ Tacrolimus, MTX= Methotrexat, $\mathrm{P}=$ Pimecrolimus, $\mathrm{C}=\mathrm{Colchicine}$, ANA= Antinuclear antibody, $\mathrm{F}=$ female, $\mathrm{M}=$ male

were observed on the leg and also on the abdomen.

One girl had LS on the genital area and also morphea lesions on the trunk, the diagnosis of which had been proved histopathologically. None of the patients had oral involvement. All patients with genital involvement (also including the boy) suffered from intense itching. Those with extragenital lesions did not have any itching and were only complaining about the appearance.

In terms of accompanying diseases, there was a case with thyroid disease and another with vitamin B12 deficiency, two patients had vitamin D deficiency and another one with iron deficiency. One patient has neurofibromatosis. No family history of LS or autoimmune disease (rheumatologic disease, thyroid disease, vitiligo, diabetes etc.) history in the families had been observed in any of the cases. One of the subjects with extragenital involvement had a severe sunburn history on his back. Following the examinations made for this study, no infectious agent and/or disease, that could have triggered the disease, was detected. Only 2 girls had ANA positivity (at 1/100 titer,13.3\%). AntidsDNA, anti-histon antibody, anti- scleroderma 70, Borrelia burgdorferi antibodies were negative.

As a first option, topical potent steroid (mometasone furoate) was given to the patients. Subjects who did not respond within 3 months were given pimecrolimus and/ or tacrolimus (for about 3 months). A patient with segmental extragenital lesions spreading to the leg and trunk was given methotrexate (MTX) and 
topical tacrolimus treatment for 6 months. The patient's lesions improved. Another patient with segmental spread blaschkoid involvement on the leg was given colchicine and tacrolimus treatment for 9 months. The male patient developed balanitis that led to phimosis and was circumcised. Relapse was observed in two patients, one with genital the other with extragenital involvement. One of these patients had been given colchicine, the other had been given topical steroid. The relapse was observed 10 years after the end of treatment. After relapse, the first patient was treated with colchicine and topical tacrolimus, the second patient was treated only with topical tacrolimus.

\section{Discussion}

This study focused on 15 children diagnosed with LS and the factors possibly related to its etiology, in addition demographic characteristics and treatment options have been assessed. Findings such as starting age of the disease, gender ratio, morphologic characteristics of lesions and disease duration were similar to the literature, but the sites of involvement regarding extragenital involvement were different (Table II). Literature indicates that girls are affected 4-10 times more often than boys. $3,9,14$ This ratio was much higher in this study, 14/1. LS appears during childhood at around $7-15 \%$ of the cases and it is mostly between the ages of $3-14 .{ }^{15} \mathrm{In}$

Table II. The comparison of our study with the literature.

\begin{tabular}{|c|c|c|c|c|c|}
\hline $\begin{array}{l}\text { Studies Time (Year) } \\
\text { Number of Patients }\end{array}$ & $\begin{array}{l}\text { Age range } \\
\text { (Years) }\end{array}$ & Area involved & $\begin{array}{l}\text { Accompanying } \\
\text { Disease }\end{array}$ & Therapy & $\begin{array}{l}\text { Complications, } \\
\text { Relapse, } \\
\text { improvement }\end{array}$ \\
\hline $\begin{array}{l}\text { Current study } \\
15\end{array}$ & $5-17$ & $\begin{array}{l}9 \text { Genital/ } \\
6 \text { Extra genital }\end{array}$ & $\begin{array}{l}\text { Vitamin B12 } \\
\text { deficiency } \\
\text { Thyroid diseases } \\
\text { Morphea }\end{array}$ & $\begin{array}{l}\text { Topical potent } \\
\text { steroid } \\
\text { Calcipotriol, } \\
\text { Tacrolimus, } \\
\text { Methotrexat, } \\
\text { Pimecrolimus, } \\
\text { Colchicine, }\end{array}$ & $\begin{array}{l}\text { - } \\
2 \text { Relapses }(13.4 \%) \\
86.6 \% \text { clearance }\end{array}$ \\
\hline $\begin{array}{l}\text { Nerantzoulis et al. } 2017 \\
15\end{array}$ & $4-19$ & Genital & - & $\begin{array}{l}\text { Topical potent } \\
\text { steroid }\end{array}$ & $\begin{array}{l}\text { Phimoses } \\
\text { Labial adhesion } \\
5 \text { Relapses }\end{array}$ \\
\hline $\begin{array}{l}\text { Anderson et al. } 2016 \\
14\end{array}$ & $2-10$ & $\begin{array}{l}\text { 13 - Genital/ } \\
\text { 1-Extra genital }\end{array}$ & - & $\begin{array}{l}\text { Topical potent } \\
\text { steroid } \\
\text { Tacrolimus }\end{array}$ & $93 \%$ clearance \\
\hline $\begin{array}{l}\text { Casey et al. } 2015 \\
72\end{array}$ & $3-14$ & Genital & - & $\begin{array}{l}\text { Topical potent } \\
\text { steroid }\end{array}$ & $72.6 \%$ clearance \\
\hline $\begin{array}{l}\text { Jensen et al. } 2012 \\
36\end{array}$ & $1-18$ & Genital & - & $\begin{array}{l}\text { Topical potent } \\
\text { steroid } \\
\text { Tacrolimus }\end{array}$ & - \\
\hline $\begin{array}{l}\text { Cooper et al. } 2004 \\
74\end{array}$ & $0-16$ & Genital & - & $\begin{array}{l}\text { Topical potent } \\
\text { steroid }\end{array}$ & $\begin{array}{l}22 \% \text { clearance } \\
67 \% \text { partial }\end{array}$ \\
\hline $\begin{array}{l}\text { Helm et al. } 1991 \\
33\end{array}$ & $<18$ & Genital & $\begin{array}{l}\text { Hypothyroidism } \\
\text { Diabetes mellitus } \\
\text { Alopecia areata }\end{array}$ & $\begin{array}{l}\text { Topical potent } \\
\text { steroid }\end{array}$ & $44 \%$ clearance \\
\hline $\begin{array}{l}\text { Meyric Thomas et al. } \\
1988 \\
47\end{array}$ & $0-20$ & Genital & $\begin{array}{l}\text { Thyroid diseases } \\
\text { Diabetes mellitus } \\
\text { Anemia }\end{array}$ & - & - \\
\hline
\end{tabular}


some studies, the average age when symptoms appeared in girls with vulvar involvement was 5-5.4 years, age of diagnosis was 6.7-7.6, and delay in diagnosis was 1-1.6 years. ${ }^{11,14,17,29,30}$ Nerantzoulis et al..$^{31}$ reported the average age for vulvar involvement in children as 8.8 and a diagnosis delay of 7 months. The age range of subjects in this current study was 5-17. Even though the average age was 11.6, the diagnosis duration was 3.9 years. The reason for delayed diagnosis in our study could be related to the fact that patients were followed by different disciplines of medicine which may have caused a delay for them to reach dermatologists.

Previous studies reported $10-17 \%$ ratio of family history in LS patients, which indicates a genetic susceptibility. ${ }^{11,15,17,32}$ However, none of the subjects involved in this study had any family history which was asked to the parents. This could be due to having a low number of patients and a lack of information on the medical charts.

In LS etiology, various triggering factors such as trauma, severe sunburns and surgical operations have been blamed. . $10,15,33^{3}$ One of the subjects with extragenital involvement had a severe sunburn history in his back. This was thought to have triggered the disease with koebnerization effect.

Some studies reported a connection between LS and various infectious agents such as Borrelia, Ebstein Bar Virus, Hepatitis C, Human Papilloma Viruses.,34-37 However, findings of studies concerning these viruses are contradictory.,13,38 While some studies found them to be meaningful, others could not establish any connection. ${ }^{7}$ In the current study we were not able to detect any infectious agents and/or disease, that could have triggered the disease. In LS, immunity associated autoimmune diseases are reported in 4-24\%, autoantibody positivity is reported to range between $42 \%$ and $80 \%$ in all age group. $8,10,12,14,33,39$ The clinical and prognostic importance of these antibodies is not known. They may be important for studying the accompanying disease. In our study, 13\% of the children had positive ANA positivity (at $1 / 100$ titer), and $6 \%$ of the children had an autoimmune disease..$^{12,33}$ Kreuter et al. ${ }^{40}$ found ANA positivity as $9.6 \%$ for females and $0.7 \%$ for males, but they did not specify the child rate. The female patients with LS more often had autoimmune diseases when compared to males in their study (respectively,18.9\%, 5.1\%). We also observed that autoimmunity was more common in the girls with LS although we only had one male patient. Circulating antibodies against IgG extracellular matrix 1 (ECM1) proteins were detected in $74 \%$ in the literature. ${ }^{1,18,41}$ We did not evaluate anti-ECM1 antibody levels in the 15 children in our study.

Clinically, there are two types of involvements in LS; genital and extragenital. Genital involvement occurs in around $80-95 \%$. In this study, genital type LS was also more common, by a ratio of $60 \%$. Genital LS diagnosis can be made simply by clinic data and history. Vulvar involvement is very frequent in LS. Erosion, ecchymosis and similar findings can be observed due to severe itching (Fig. 1). Sexual abuse should also be part of the differential diagnosis as ecchymosis and petechial focuses are seen in the genital area. Referring these patients to dermatology clinics

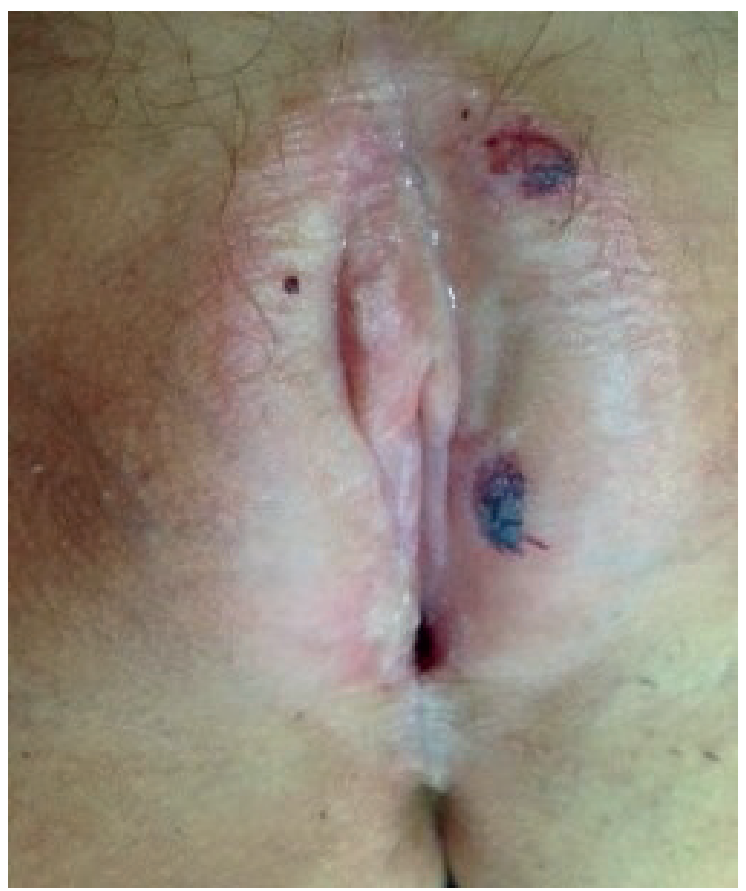

Fig. 1. The ulcers on genital lichen sclerosus lesions. 
is important to ensure a correct diagnosis. ${ }^{17}$ The patients in the current study also had itching. However, petechia and ecchymosis were observed in only 2 subjects. The possibility of sexual abuse was investigated for these children with ecchymosis and petechial focuses but none could be determined. ${ }^{13}$

Ulceration, dysuria and painful defecation may also occur in these patients. The existence of genital itching simplifies the lesions to be more widespread and permanent due to the koebnerization characteristic of LS. Due to scar formation over time, the anatomic structure of the genital area may be distorted, leading to vaginal tightness in girls, and phimosis in boys, along with other issues for both genders. ${ }^{17,30,39,42}$ Smith et al. ${ }^{16}$ observed in $25 \%$ healing in LS, also reporting that $75 \%$ of the symptoms continued and that the change in vaginal appearance is $50 \%$. Despite reacting to treatment in the study, 2 relapses developed.

In some studies, LS has been detected in 9-52\% of the boys with phimosis. ${ }^{11,29}$ In another study, $57 \%$ which is localized to the foreskin, $4 \%$ with meatal involvement and 20\% with urethral involvement have been reported. ${ }^{43}$ The age of observing balanitis in boys has been detected as 28 months- 18years ( 8 years in average)..$^{29,43}$ The only boy in the study with penis involvement was 10 years old and he had been suffering from phimosis for 3 years. Extragenital lesions are seen in $15-20 \%$ of the patients. These lesions may be seen along with anogenital lesions ${ }^{3,9}$ Isolated skin involvement is around 6\%. In general, the upper trunk, axilla, femur, hips are more frequently involved while the face, hairy skin, hands and feet are more rarely involved. ${ }^{7,8,14}$ (Figs 2 and 3). Another interesting finding of the study was that extragenital involvement were in the form of isolated involvement. Some authors have detected $4 \%$ of extragenital involvement ${ }^{11-15}$, but this rate was higher in this study $(40 \%){ }^{12}$

For patients with extragenital involvement to be able to diagnose LS, diseases such as atrophic lichen planus, cicatricial pemphigoid, lichen simplex chronicus, psoriasis, contact dermatitis, morphea, lichen niditus, porokeratosis, vitiligo, idiopathic guttate hypomelanosis, discoid lupus eritematosus have to be considered in the differential diagnosis and a biopsy should be taken. ${ }^{16}$

In the histopathology of LS, there is band type lymphocytic infiltration at the surface dermis and vacuolar degeneration at the basal layer during the early stages and thickening due to lower infiltration, sclerosis in dermis and fibrosis and also atrophy in the epidermis during the latter stages. ${ }^{9,24}$

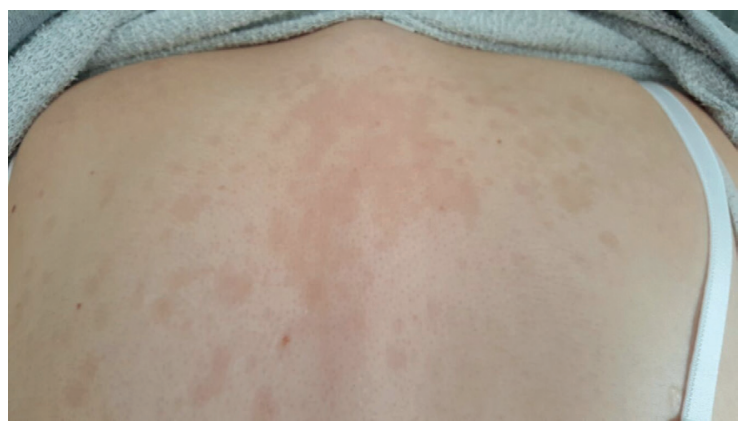

Fig. 2. Lichen sclerosus lesions on the back.

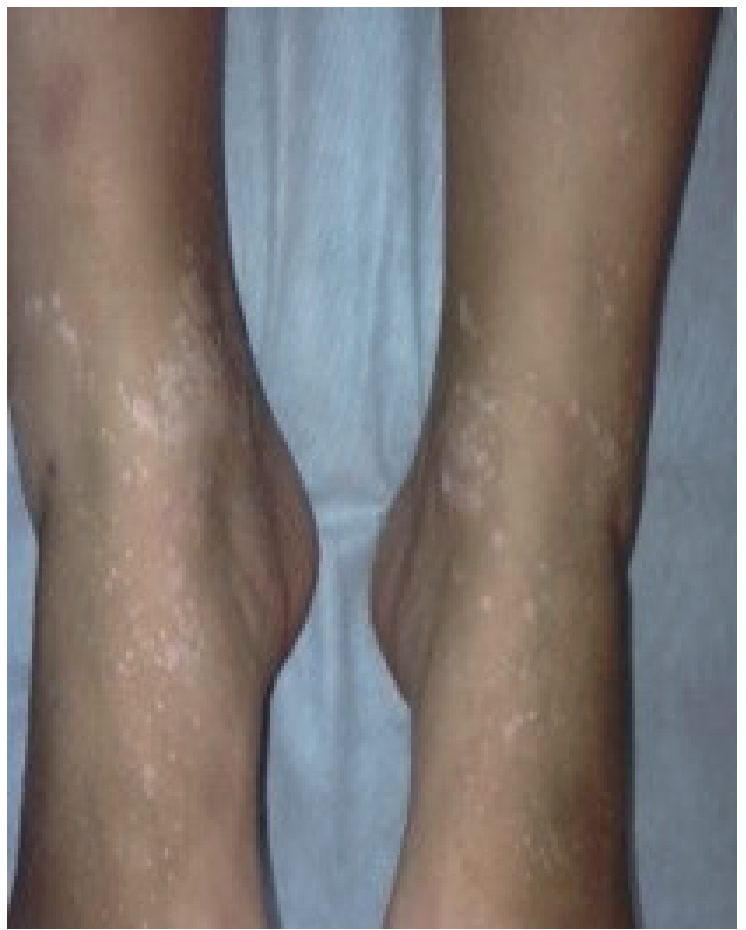

Fig. 3. Lichen sclerosus lesions on the dorsum of the foot. 
In this study, the definitive diagnosis of patients with extragenital involvement have been given by assessment under the light of these histopathologic findings. Lesions were mostly placed in the trunk and lower extremity. Lesions in 2 cases on the lower extremity were spread and blaschkoid type (Fig. 3). This is also a rare event and only a few cases have been reported in literature. ${ }^{19-21}$

The literature also contains oral lesion involvement. ${ }^{25}$ However, no oral involvement was observed in this study. The existence of autoimmune disease has been observed in $12-42 \%$ of LS patients. ${ }^{10-12,17,22,33,39}$ The most frequent among these are thyroid disease, vitiligo, irritable intestine disease, alopecia areata, rheumatoid arthritis, pernicious anemia, morphea, psoriasis, atopic dermatitis and diabetes mellitus coexistence. , $12,15,33,45$ Murphy et al. ${ }^{44}$ observed $12 \%$ of thyroid pathology and $2 \%$ of pernicious anemia. It has been reported that autoimmunity is more common in girls with genital involvement. ${ }^{7,42}$ In this study, thyroid disease was observed in $6 \%(\mathrm{n}=1)$, and Vitamin B12 deficiency anemia in 13\%. In addition, with regards to accompanying diseases, two patients had vitamin D deficiency and one case had iron deficiency anemia.

Extragenital LS accompanied by a plaque type morphea is a frequent event and some authors claimed that they have a common pathogenesis. ${ }^{22,45}$ In this study, morphea coexistence was detected in one subject with genital involvement. As the reason for lichen sclerosis is not fully known, there is no effective treatment for it. The purpose of the treatment is to minimize the development of the disease during the early stages to prevent functional and cosmetic complications. . $^{18,46,47}$ Therefore, early diagnosis, treatment and follow-up are thought to be significant. For the treatment of LS with genital involvement, use of potent local steroids is recommended. This type of treatment is thought to be reliable and effective. . $^{3,13,31,46,47,51-53}$

As a first option, we preferred potent steroid creams for our subjects. Due to the atrophy risk in topical corticosteroids, use of topical calcineurin inhibitors has been considered for treatment in recent years. ${ }^{13,18,30,46,51,52}$ Patients not benefiting from the treatment were given topical calcineurin inhibitors, topical calsipotriol and betametazon. In limited lesions phototherapy (UVA1, narrowbant UVB, UVA) is among the other treatment options for both genital and extragenital type LS. ${ }^{7,47}$ However, none of our patients were given phototherapy. Lesions in the extragenital areas do not respond to topical steroid treatment as much as genital disease. In the literature, different treatments such as topical calcineurin inhibitors, systemic retinoids UVB, PUVA, UVA, oral stanozolol, topical oxatomide, topical calcipotriol, antimalarials and various antibiotics have been tried. ${ }^{66,47}$ In this study, we administered topic tacrolimus and pimecrolimus therapy as well as topical steroids in patients with extragenital involvement.

Methotrexate (MTX) may be given to patients with LS. ${ }^{48}$ In our study, we administered MTX therapy to a patient with multiple extragenital lesions for 6 months. Lesions improved leaving post-inflammatory hyperpigmentation.

A study conducted in Turkey by Parlak et al. ${ }^{49}$ on patients with morphea, reported that giving colchicine stopped the formation of new lesions and that the side effect profile was low, thus it could be an effective and reliable option. Considering the joint pathogenesis of LS and morphea, a subject with blaschkoid type spread lesions was given colchicine treatment for 9 months, due to the fibroblast inhibition, effect on elastic fibers and anti-inflammatory aspects of this drug. ${ }^{50}$ The lesions improved with postinflammatory hyperpigmentation, however, relapse developed in the lesions after a few years.

There is no need for surgery in non-complicated LS, surgical methods should only be used in the presence of malignity when correcting cicatrix. ${ }^{46}$ In the genital area of boys the most frequent involvement is seen in the foreskin, therefore burning, difficulty in pulling back the foreskin, 
micturition difficulty can be experienced and phimosis could develop. ${ }^{46}$ Accordingly in this study, a male subject had to be circumcised due to developing phimosis. Clinic progress of LS is not clear as it changes. There is a belief that healing occurs in most patients by puberty. ${ }^{17,42}$ In some studies, it has been reported that lesions fully heal up to $25 \%$, while there is symptomatic healing in 75-93\%, and this could recur. ${ }^{54}$ Studies have concluded that vulvar anatomy deforms by $20-50 \%$ despite treatment. ${ }^{13,16,30,53,54}$ In addition, it may lead to functional deformities such as micturition disorder and constipation. Cooper et al. ${ }^{39}$ reported a $60 \%$ recurrence in girls that they have monitored for 15 years. In this study, lesions in most of the girls with vulvar involvement were improved through treatment.

Only a subject with thyroid pathology had recurring lesions recurred after puberty. This could indicate that there is a possibility of recurrence in patients with autoimmunity. Some studies concluded that the disease does not regress by puberty, emphasizing the need for careful monitoring of the patients for malignity development risk. ${ }^{16,42,54}$ In adults, malignity development ranges between 4-5\%., ${ }^{8,12}$ Malignity in childhood is considered to be non-existent, however, malignity has been reported in the literature in a subject with genital involvement that started during childhood and continued in adulthood. ${ }^{42}$ Therefore, early diagnosis and treatment are thought to be important for these patients. The purpose is to control symptoms, prevent and treat complications and detect malignity in the early stages. A multidisciplinary approach is required. Following proper treatment in girls with the genital lesion, no permanent deformation developed in any of them. Extragenital lesions do not have any malign change risk. No malignity development was observed during the follow-up of any of our patients with genital involvement. By affecting deeper tissues, extragenital lesions can lead to deformation. No deformation has been observed in our patients.
The most common form of childhood LS is genital type, as observed in our study. Genital itching was the most frequent symptom. Therefore, LS must be considered in the differential diagnosis of genital itching in children. Patients should be carefully questioned in terms of symptoms and examined. Extragenital involvement could be at a considerable degree in LS. In genital involvement that continues for a long time and resists treatment, a biopsy must be done to exclude malignity.

LS is a chronic disease that progresses with recurrences and regressions. A self-regression may be observed in girls after menarche. ${ }^{54}$ However, the risk of recurrence during adulthood is not exactly known. Diagnosis and treatment at early stages is important in LS, due to cosmetic and functional deformities that may progress severely. Therefore, family physicians, pediatricians, gynecologists, urologists and dermatologists should work in collaboration. The limiting factors of this study were its retrospective nature, few number of patients and the lack of detailed family history. In order to achieve more definite data, more comprehensive, prospective multicenter studies are needed.

\section{REFERENCES}

1. Rőcken M, Ghoreschi K. Morfea ve liken skleroz. Bolognia JL, Jorizzo JL, Rapini RP (eds). Dermatoloji (2. Basım) Cilt 2. İstanbul: Nobel Kitapevi, 2012: 1462-1476.

2. Hallopeau H. Lichen plan sclereux. Ann Dermatol Syph 1889; 10: 447-449.

3. Monsálvez V, Rivera R, Vanaclocha F. Lichen sclerosus. Actas Dermosifiliogr 2010; 101: 31-38.

4. Tong LX, Sun GS, Teng JM. Pediatric lichen sclerosus: a review of the epidemiology and treatment options. Pediatr Dermatol 2015; 32: 593-599.

5. Neill SM. Vulvovajinitis and lichen sclerosus In: Harper J, Orange A, Prose N (eds). Texbook of Pediatric Dermatology. (2nd ed) Vol 2. Massachusetts: Blackwell Science, 2006: 1822-1826.

6. Morrel B, van Eersel R, Burger CW, et al. The longterm clinical consequences of juvenile vulvar lichen sclerosus: a systematic review. J Am Acad Dermatol 2020; 82: 469-477. 
7. Fistarol SK, Itin PH. Diagnosis and treatment of lichen sclerosus: an update. Am J Clin Dermatol 2013; 14: 27-47.

8. Nair PA. Vulvar Lichen sclerosus et atrophicus. J Midlife Health 2017; 8: 55-62.

9. Ergin S. Liken sklerozus. Türk Dermatoloji Dergisi 2012; 6: 27-34.

10. Bercaw-Pratt JL, Boardman LA, Simms-Cendan JS; North American Society for Pediatric and Adolescent Gynecology. Clinical recommendation: pediatric lichen sclerosus. J Pediatr Adolesc Gynecol 2014; 27: 111-116.

11. Paller AS, Mancini AJ. Collogen vasculer disorders. In: Hurwitz Clinical Pediatric Dermatology: A Textbook of Skin Disorders of Childhood and Adolescence. (3rd ed). Chine: Elsevier Inc, Saunders, 2006: 599-600.

12. Meyric Thomas RH, Ridley CM, Mc Gibbon DH, Black MM. Lichen sclerosus et atrophicus and autoimmunity: a study of 350 women. Br J Dermatol 1988; 118: 41-46.

13. Neill SM, Lewis FM, Tatnall FM, Cox NH; British Association of Dermatologists. British Association of Dermatologists' guidelines for the management of lichen sclerosus 2010. Br J Dermatol 2010; 163: 672-682.

14. Dinh H, Purcell SM, Chung C, Zaenglein AL. Pediatric lichen sclerosus: a review of the literature and management recommendations. J Clin Aesthet Dermatol 2016; 9: 49-54

15. Kirtschig G. Lichen sclerosus-presentation, diagnosis and management. Dtsch Arztebl Int 2016; 113: 337-343.

16. Smith SD, Fischer G. Childhood onset vulvar lichen sclerosus does not resolve at puberty: a prospective case series. Pediatr Dermatol 2009; 26: 725-729.

17. Powell J, Wojnarowska F. Childhood vulvar lichen sclerosus: an increasingly common problem. J Am Acad Dermatol 2001; 44: 803-806.

18. Chi CC, Kirtschig G, Baldo M, et al. Systematic review and meta-analysis of randomized controlled trials on topical interventions for genital lichen sclerosus. J Am Acad Dermatol 2012; 67: 305-312.

19. Gutte R, Khopkar U. Extragenital unilateral lichen sclerosus et atrophicus in a child: a case report. Egyptian Dermatol J 2011; 7: 10.

20. Viana Fde O, Cavaleiro LH, Unger DA, Miranda MF, Brito AC. Acral lichen sclerosus et atrophicuscase report. An Bras Dermatol 2011; 86(4 Suppl 1): S82-S84.
21. Kim CR, Jung KD, Kim $H$, et al. Linear lichen sclerosus along the Blaschko's line of the face. Ann Dermatol 2011; 23: 222-224.

22. Kreuter A, Wischnewski J, Terras S, Altmeyer P, Stücker M, Gambichler T. Coexistence of lichen sclerosus and morphea: a retrospective analysis of 472 patients with localized scleroderma from a German tertiary referral center. J Am Acad Dermatol 2012; 67: 1157-1162.

23. Bjekić M, Šipetić S, Marinković J. Risk factors for genital lichen sclerosus in men. Br J Dermatol 2011; 164: 325-329.

24. Carlson JA, Lamb P, Malfetano J, Ambros RA, Mihm MC Jr. Clinicopathologic comparison of vulvar and extragenital lichen sclerosus: histologic variants, evolving lesion, and etiology of 141 cases. Mod Pathol 1998; 11: 844-854.

25. Tomo S, Santos IS, de Queiroz SA, Bernabé DG, Simonato LE, Miyahara GI. Uncommon oral manifestation of lichen sclerosus: critical analysis of cases reported from 1957 to 2016. Med Oral Patol Oral Cir Bucal 2017; 22: e410-e416.

26. An İ, Uçmak D, İbiloğlu İ. Çocukluk çağında görülen ekstragenital yerleşimli liken skleroz: dört olgu sunumu. Turkiye Klinikleri J Dermatol 2017; 27 109-112.

27. Tepe B, Erdoğdu Hİ, Aydın Türk B. İki çocukta extragenital lokalizasyonlu liken skleroz. Turkiye Klinikleri J Dermatol 2016; 26: 117-120.

28. Kandi CB, Saral Y, Ataseven A, Özercan İH, Çiçek D. Çocukluk çağında görülen ekstragenital yerleşimli liken sklerozis olgusu: Firat Tip Dergisi 2004; 9: 6264 .

29. Celis S, Reed F, Murphy F, et al. Balanitis xerotica obliterans in children and adolescents: a literature review andclinical series. J Pediatr Urol 2014; 10: 34 39.

30. Jensen LS, Bygum A. Childhood lichen sclerosus is a rare but important diagnosis. Dan Med J 2012; 59: A4424.

31. Nerantzoulis I, Grigoriadis T, Michala L. Genital lichen sclerosus in childhood and adolescence-a retrospective case series of 15 patients: early diagnosis is crucial to avoid long-term sequelae. Eur J Pediatr 2017; 176: 1429-1432.

32. Sherman V, McPherson T, Baldo M, Salim A, Gao $\mathrm{XH}$, Wojnarowska $\mathrm{F}$. The high rate of familial lichen sclerosus suggests a genetic contribution: an observational cohort study. J Eur Acad Dermatol Venereol 2010; 24: 1031-1034.

33. Helm KF, Gibson LE, Muller SA. Lichen sclerosus et atrophicus in children and young adults. Pediatr Dermatol 1991; 8: 97-101. 
34. Eisendle K, Grabner T, Kutzner H, Zelger B. Possible role of Borrelia burgdorferi sensu lato infection in lichen sclerosus. Arch Dermatol 2008; 144: 591-598.

35. Aberer E, Stanek G. Histological evidence for spirochetal origin of morphea and lichen sclerosus et atrophicans. Am J Dermatopathol 1987; 9: 374-379.

36. Edmonds E, Mavin S, Francis N, Ho-Yen D, Bunker C. Borrelia burgdorferi is not associated with genital lichen sclerosus in men. Br J Dermatol 2009; 160: 459460 .

37. Aidé S, Lattario FR, Almeida G, do Val IC, da Costa Carvalho M. Epstein-Barr virus and human papillomavirus infection in vulvar lichen sclerosus. J Low Genit Tract Dis 2010; 14: 319-322.

38. Ozkan S, Atabey N, Fetil E, Erkizan V, Günes AT. Evidence for Borrelia burgdorferi in morphea and lichen sclerosus. Int J Dermatol 2000; 39: 278-283.

39. Cooper SM, Ali I, Baldo M, Wojnarowska F. The association of lichen sclerosus and erosive lichen planus of the vulva with autoimmune disease: a case-control study. Arch Dermatol 2008; 144: 14321435 .

40. Kreuter A, Kryvosheyeva Y, Terras S, et al. Association of autoimmune diseases with lichen sclerosus in 532 male and female patients. Acta Derm Venereol 2013; 93: 238-241.

41. Oyama N, Chan I, Neill SM, et al. Autoantibodies to extracellular matrix protein 1 in lichen sclerosus. Lancet 2003; 362: 118-123.

42. Powell J, Wojnarowska F. Childhood vulvar lichen sclerosus. The course after puberty. J Reprod Med 2002; 47: 706-709.

43. Depasquale I, Park AJ, Bracka A. The treatment of balanitis xerotica obliterans. BJU Int 2000; 86: 459465.

44. Murphy R. Lichen sclerosus. Dermatol Clin 2010; 28: 707-715.
45. Ceylan N, Gürel MS, Kiremitçi Ü, Demirkesen C. Jeneralize morfea-liken skleroatrofik birlikteliği. Türk Patoloji Dergisi 2008; 24: 179-182.

46. Bunker CB. Comments on the British Association of Dermatologists guidelines for the management of lichen sclerosus. Br J Dermatol 2011; 164: 894 -895.

47. Kirtschig G, Becker K, Günthert A, et al. Evidencebased (S3) guideline on(anogenital) lichen sclerosus. J Eur Acad Dermatol Venereol 2015; 29: e1-e43.

48. Kreuter A, Gambichler T, Breuckmann F, et al. Pulsed high-dose corticosteroids combined with low-dose methotrexate in severe localized scleroderma. Arch Dermatol 2005; 141: 847-852.

49. Parlak N, Akay BN, Şanlı HE, Akyol A. Morfeal hastalarda klinik özellikler, laboratuvar bulguları, seçilen tedavi yöntemi ve takip sonuçları. TurkdermDeri Hastalıkları ve Frengi Arşivi Dergisi 2013; 47: 209-213.

50. El-Sakka AI, Bakircioglu ME, Bhatnagar RS, Yen TS, Dahiya R, Lue TF. The effects of colchicine on a Peyronie's-like condition in an animal model. J Urol 1999; 161: 1980-1983.

51. Anderson K, Ascanio NM, Kinney MA, Krowchuk DP, Jorizzo JL. A retrospective analysis of pediatric patients with lichen sclerosus treated with a standardprotocol of class I topical corticosteroid and topical calcineurin inhibitor. Dermatolog Treat 2016; 27: 64-66.

52. Casey GA, Cooper SM, Powell JJ. Treatment of vulvar lichen sclerosus with topical corticosteroids in children: a study of 72 children. Clin Exp Dermatol 2015; 40: 289-292.

53. Cooper SM, Gao XH, Powell JJ, Wojnarowska F. Does treatment of vulvar lichen sclerosus influence its prognosis? Arch Dermatol 2004; 140: 702-706.

54. Focseneanu MA, Gupta M, Squires KC, Bayliss SJ, Berk D, Merritt DF. The course of lichen sclerosus diagnosed prior to puberty. J Pediatr Adoles Gynecol 2013; 26: 153-155. 